\title{
Social Justice In The Implementing Zoning School Policy (Case Study in Temanggung Regency)
}

\author{
Yunike Sulistyosari ${ }^{1}$, Siti Irene Astuti Dwiningrum ${ }^{2}$ \\ Universitas Negeri Yogyakarta,Indonesia ${ }^{1}$, Universitas Negeri Yogyakarta' Indonesia ${ }^{2}$ \\ Yunikesulistyosari.2018@student.uny.ac.id ${ }^{1}$,siti_ireneastuti@uny.ac.id ${ }^{2}$
}

\begin{abstract}
Social justice is a principle that will be achieved through zoning policies to accelerate the participation of education. In practice, there is a relationship between education policy and social justice, the complexity of justice is following the individual who runs it, but the social justice principle policy for the community has not been realized. This research uses a qualitative method with a case study approach. The object of this research is Temanggung Regency. This research was conducted in September 2019 to January 2020. The results showed that the zoning policy gave rise to parental disappointments such as the occurrence of blank spot areas, restrictions on choosing schools, and national exam scores that were not used in-school registration. The factors underlying the injustice in the community are the unequal condition of facilities and infrastructure in each school and the distribution of schools in each region that is not the same.
\end{abstract}

Keywords: social justice, zoning policy.

\section{Introduction}

Education is the basic foundation for political, social, and economic development in each country. Indonesia as a developing country still faces many challenges in the field of equal access and quality of education. Thus the need for educational policies in directing educational activities in the direction of national education policy. The determination of educational policies in each region varies according to the constitutional hierarchy that applies in each region. At present, the implementation of education policy in Indonesia is not yet applicable to the policy goals. This has resulted in educational inequality in a region. According to[1]. the idealism of the nation's education direction at the level of educational policy to date has been limited to mere slogans. In practice, factually, it has not been able to reach the direction of national education policy.

Portrait of education in Indonesia in 2017 there is $4.98 \%$ of the population in Indonesia who did not continue their education at the age of 13-15 years or the junior secondary school level[2]. Based on education statistics in 2018, there are $4.11 \%$ of Indonesia's population who did not continue their education at the first or the same level of secondary school [3]. The persistence of school-aged children who do not attend school indicates that the compulsory education program which is the 2015-2019 RPJMN has not been achieved. Until now, policies in Indonesia are still making changes in the face of developments in the current global era.

The applicable educational policies implemented by a country can enable the achievement of national goals. So that policy reconstruction is needed so that what is implemented has real relevance. According to Gunter, educational policy in the UK was formed based on critical knowledge to produce a policy model that was in line with the target[4]. Based on the results of these studies indicate that the role of education policy is very important in achieving quality education. The educational policy must have clear and directed goals. 
The government's effort to alleviate the problem of educational equity is through zoning system policies. This system is applied to the acceptance of new students (PPDB). The zoning system used in Indonesia is guided by Permendikbud No. 14 of 2018 which is based on the distance radius in the selection of student admissions. The distance radius is set $6 \mathrm{Km}$ from the residence to the school[5]. The purpose of the zoning system is to fulfill the rights of citizens to obtain access to education services, eliminate discrimination in favorite schools, and increase the heterogeneity of students in schools.

However, the implementation of the zoning system policy is still responded negatively by some people. The zoning system is against the interests of the community. The unequal condition of school facilities is a source of injustice when accepting new students with zoning policies. This is supported by research[6]. that the zoning system that leads to the closeness of schools has not resulted in equal distribution because it has not been supported by uniform school conditions, resulting in the right of individuals to get a school instead becomes limited. Based on existing research that justice in education still needs to be explored more deeply. The implementation of zoning policies that are based on the justice of all citizens in getting their rights in the field of education, but in reality on the ground there are still protests from various parents in demanding justice. This divestment will explore data related to the form of injustice that occurs and the source of the background of injustice that occurs.

\section{2 methods}

This study uses a qualitative method with the Cresswell el case study approach. This research was conducted in September 2019 in the Temanggung Regency, covering SMP N 5 Temanggung, SMP N 1 Gemawang, Department of Education Office Temanggung Regency, and several villages in Parakan and Gemawang District. This research focuses on the experience of parents when registering their children through the zoning system because the zoning system was first implemented in Temanggung Regency. Informants in the study were selected based on their involvement in implementing the zoning system policy.

This research takes data directly in the form of primary data through data collection techniques with observation and interviews. Whereas secondary data is obtained through documents. Data collection techniques carried out through interviews, observation, and study of documents. The validity of the data is done by technique triangulation and source triangulation. Data analysis is done by organizing data, reading and making memos, describing data, clarifying data, interpreting data, and presenting data. This qualitative research uses grounded theory analysis which develops theories based on systematic analysis. The purpose of grounded theory is to explain phenomena by identifying. Categorizing relationships and processes in research.

\section{Results And Discussion}

Based on the results of research on the implementation of zoning policies in the scope of the District, found several findings that have not been aligned with the policy objectives, namely policies that provide justice in society. 


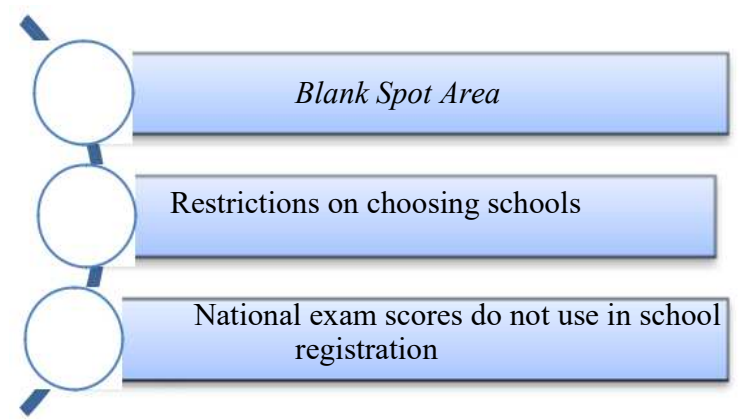

Fig.1. Forms of Injustice in the community

Based on the findings above, it shows that the implementation of zoning system policies has not yet reached the goal, because it still faces injustice in the community. Changes in policies designed by creating justice and equity, but the implementation has not been felt by the community at all. The community is disappointed with the zoning policy because of the injustice in obtaining rights. The right referred to in this context is the right to education.

Indonesia's geographical conditions are not all flat, and the uneven distribution of public schools, these two aspects are indicators that must be considered when the policy is implemented. The zoning policy which focuses on the distance from domicile to school certainly has a positive impact on those who live near home, but for people who live in remote areas far from schools that have negative impacts. The following is the description of injustice that occurred when implementing the zoning policy.

\subsection{Blank Spot Area}

The location of residence is a blank spot area, meaning that the area does not have the opportunity for a school in-state junior high school, whereas if it is examined in a distance that does not exceed 6 $\mathrm{km}$, so it is difficult to get a public school, the coordinates of the place of residence are not following the original and there are complaints related to falsification of domicile certificate. The researchers' meeting showed the disappointment of parents in addressing the zoning system. The enactment of the zoning system limits children's rights to choose schools. This condition occurs in areas that are blank spots. Children who are in the blank spot area have not yet received special treatment from the ministry, in addition to attending private schools.

The occurrence of blank spot areas in regions in the Temanggung Regency, in particular, is an evaluation of the implementation of zoning system policies. The inadequate planning process was also conveyed by the chairman of the PPDB committee that preparations for implementing the zoning system policy in Temanggung Regency were indeed still lacking, Temanggung's uneven condition of the region actually needed to be mapped in advance but due to the very urgent time so we only carried out the policy this alone is following the mandate of the central government.

\subsection{Limitations of Students Choosing Schools}

The unequal condition of public schools in Temanggung Regency has been analyzed by researchers, that the distribution of state junior high schools in Temanggung subdistrict there are 6 state junior high schools while there are several subdistricts that have only 1 state junior high school, for example, SMP N 1 Gemawang which is included in the suburbs with densely populated but there is 
only one school. Such is the condition in several regions that do not yet support zoning policy implementation.

Based on the results of the study of documents and interviews that the uneven distribution of schools affects the opportunities for students to enroll in public schools and can affect the fulfillment of quotas in each school. the spread of schools is a cause of conflict in the implementation of the zoning system. The previous year the distribution of schools did not become a serious problem in education because in PPDB the only consideration was the value of distance. Whereas the zoning system prioritizes the distance of residence and school so that this zoning system can harm students who do not have a public school in the vicinity of their residence.

Gemawang Subdistrict, which is on the outskirts of Temanggung, only has one state junior high school, while in one sub-district there are 10 villages. This has become a loss felt by the community when the zoning system policy is applied because the choice of state schools only exists at SMP N 1 Gemawang. Some villages are difficult to access to SMP N 1 Gemawang, for example, Ngadisepi Village is constrained by transportation. The journey to the school is quite far but there is no public transportation at all, causing children to choose to go to a private school rather than to SMP N 1 Gemawang.

Based on the findings of these researchers that the zoning policy has not provided justice for all citizens. The condition of the social and geographical environment and also the distribution of facilities that have not been evenly distributed are a scourge for parents who send them to schools that were previously categorized as not favorites. So that with the new policy for parents whose economic conditions are sufficient will choose schools of good quality through moving domiciles close to favorite schools or enrolling their children in leading private schools.

\subsection{National exam scores do not use in school registration}

The difference in zoning regulations can be seen in the provisions of registration since the current policy only requires distance, so the National Examination (UN) score is not used in determining selection. This new policy makes people disappointed because from year to year the national exam scores are always the main requirement as well as the main determinant of admission to a school. Parents and students feel disappointed, after trying to study seriously even adding hours of learning through special tutoring, but after the effort is made there is a notification that registration only prioritizes the distance. The parents felt it was unfair if grades and achievements were not used inschool registration. this also has an impact on children's learning motivation. Some findings suggest that parents have difficulty in getting their children to learn, with the reason that schools do not use values so it is the same between the smart and the less smart.

Based on interviews with parents, it shows that parents do not support the early junior high school registration schedule and there are no graduation announcements yet. At the moment the registration does not have a UN score nor a diploma. The most disappointing thing is the UN score that is not used in registration either as a condition or as an achievement. Parents feel their children's learning is in vain because it is defeated by the closest distance and even socioeconomic status. The zoning policy regulations that apply in Temanggung Regency are also highlighted by policy implementers. This is because achievements owned by children cannot be used to register in their zones, so these achievements can be used outside of their zones.

The zoning policy is a new policy issued by the government based on Permendikbud Law No. 14 of 2018. School zoning is the process of identifying geographical areas to assign school-age children living in the area to several public schools for social purposes supported by political forces[5]. The zoning system is an effort of the government in terms of equalizing the quality of education in various parts of Indonesia, besides, students who have above average academic ability can spread in various 
schools so that they do not gather in some schools which are often called superior schools [7]. Through this policy the government has future planning there is no imbalance of schools in Indonesia.

The zoning system was first implemented in the United States in 1954 by the Supreme Court, to reduce racial segregation [8]. Developed countries like Europe, the United States, and Finland have used the zoning system for a long time with the ideal goal of breaking the chains of poverty and crossing racial segregation. By increasing the fulfillment of education a way to improve the quality of its human resources. based on the success of developed countries that have implemented zoning policies, so that Indonesia has made zoning policies starting in the 2018/2019 school year to create equitable educationThe implementation of the first year of course there is still many obstacles and problems, including justice. On Permendikbud No. 14 of 2018 article 2 paragraph (1) states that PPDB aims to ensure the acceptance of new students in an objective, transparent, accountable, nondiscriminatory, and just manner to encourage increased access to education services. however, in actual implementation on the ground, the concept of justice has not yet been seen. The following is a description of the injustice of the zoning policies that have occurred in Indonesia.

\subsection{Blank spot area}

Blank spot areas in the zoning system are areas that cannot reach enrollment in public schools. The location of the Temanggung Regency which is on a plateau causes the area to be uneven, as does the distribution of existing schools. Based on document studies that have been carried out, the number of state junior high schools in the Temanggung Regency is 44 schools spread throughout Temanggung. But the data shows the uneven distribution, evidenced by the number of schools in each district not the same. Based on secondary data about the distribution of state junior high schools obtained by researchers, several districts only have one state junior high school such as the Parakan, Tembarak, Jumo, Tretep, Bansari, and Gemawang Districts. While there are districts that have a large number of public schools, namely Temanggung District has six state junior high schools. Based on the research results of the zoning system policy formulation, Temanggung Regency has not yet mapped the densely populated and non-densely populated areas of the school-age population, especially in secondary level education units. Mapping the distribution of schools with populations around schools is important for the government to undertake before the zoning system is implemented because the urgency in this policy is on the distance to get schools.

This is consistent [9] that the main factors that can cause disparities between regions include: geography/distance to schools, history, the political situation in an area, and government policies towards an area and so on. Regional disparities occur in PPDB in Temanggung Regency, which is caused by the uneven distribution of public schools. Areas that have a few public schools will limit prospective students in making choices. The limitations of students in choosing public schools reap injustice in the community.

The implementation of the zoning policy that was made to answer the challenges of education at this time had not been successful. The zoning policy has implications for housing gaps. Equitable distribution of quality schools still cannot be overcome in various developed countries [10]. this is similar to what happened in Indonesia in that distance regulation is unfair for people who live in isolated areas. The government should also pay attention to areas that become blank spot areas, as well as provide alternative solutions, not only provide opportunities for choice in the private sector, given the economic situation of each family is different.

\subsection{Restrictions on choosing a school}

The influence of geographical factors in the implementation of zoning system policies in the Temanggung Regency has resulted in limited opportunities for students to choose State Junior High 
Schools. Prospective students who come from blank spot areas do not have the same opportunity to continue in state junior high school. This causes prospective students to only have one choice to continue school, namely in private schools. This condition triggers opposition to the zoning system policies. In line that injustice in the form of discrimination against individual rights can be a major source of conflict[11]. The phenomenon of the implementation of zoning system policies in the Temanggung Regency, there is a difference in the opportunity to continue to state schools, causing injustice in society. Coser Analysis [12] Injustice perceived by the community is a form of realistic social conflict. Realistic conflict arises based on disappointment with the PPDB decision using the zoning system policy. This zoning system policy does not give students the freedom to enroll in public schools for those who come from rural areas and come from blank spot areas.

The results of the analysis of researchers when examined using Fisher's theory include conflicts caused by transformation theory[13]. The theory explains the presence of conflict because of the problems of injustice in the realm of social, economic, political, and cultural life. In the implementation of PPDB, the zoning system policy changes the system in terms of entry requirements and selection of prospective students in-state junior high schools which causes injustice for prospective students. The findings of researchers obtained through interviews and document studies indicate geography as one of the factors that cause conflicts in the zoning system. The uneven layout of public schools causes injustice to the community because students are limited in choosing schools that are far from public schools. This restriction leads to injustice felt by the community. Government injustice in the zoning system policies that trigger social conflict in society.

\subsection{National exam scores do not use in school registration}

The culture of using school registration in Indonesia from year to year uses test scores as the main requirement. However, entering 2019 there is a change in the system that applies, through zoning policies that prioritize the distance from the residence to the school. This policy change has not yet been accepted by the whole community. For parents whose children have ordinary values will be very supportive, in contrast to parents who have smart children feel disappointed. This is supported from previous research that schools run by the government are obliged to accept prospective students who live in the radius of the closest zone of the school which is considered unfair because of high UN scores as a result of the seriousness of students in learning as if considered to be in vain because they were defeated by the distance between home and school or socioeconomic status [14].

Another study was carried out that in the implementation of zoning policies in Indonesia there were still many protests by parents and were inefficient [15]. Parents' protests due to the prevailing policies ignored national exam scores that were not enforced at all in getting a school. The phenomenon of the implementation of zoning system policies in the Temanggung Regency, there is a difference in the opportunity to continue to state schools, causing injustice in society. This is also supported by the opinion who explains the purpose of educational development must be done by providing opportunities for all school-age residents to obtain an education with justice for all levels of pluralistic society which is accompanied by responsibility in providing consequences that must be borne by the government and Public [16].

The implementation of zoning policies in general in Indonesia has not been able to achieve its objectives. This can be seen that there are still some problems faced, especially in achieving justice that cannot yet be realized. The things that need to be considered this injustice occurs is that the facilities and infrastructure or facilities of each school have not been evenly distributed. It can be said that Indonesia still experiences an imbalance in the quality of education. this was confirmed by previous researchers who explained that the implementation of the zoning system in Indonesia still has shortcomings and is far from justice. Because in general the facilities and infrastructure are not evenly distributed due to the disparity in vortices and non-favorite schools [17]. the existence of these facilities 
and infrastructure physically shows that favorite schools tend to be more complete than those in marginal schools.

The principle of justice in zoning policies that have not yet been achieved is reinforced by Andina which states that socialization is not yet optimal as an obstacle in conducting zoning policies fairly and thoroughly Socialization is the most important step that must be prepared in implementing the new policy. The still weak socialization in Temanggung District has resulted in many community protests to the school and the Education Office. The lack of parental knowledge about the zoning system policy occurs because the socialization has not run optimally. Information that is not delivered on target leads to the ignorance of parents and ultimately causes protests to the organizers of PPDB. The results showed parents' ignorance of the zoning system when registering their children because they did not receive socialization from the school.

\section{Conclusion}

The zoning policy in Indonesia which proceeds with justice for all Indonesian citizens has not yet been achieved. This is motivated by the quality of education in each school which is not the same and the distribution of public schools in each region is different. Inequality in the quality of education in each region is very visible, that schools that become favorite schools tend to have complete facilities and quality guaranteed, in contrast to schools that are not favorite in terms of facilities and quality are also lagging. This is what causes concern for parents and students when enrolling their children in unseeded schools. A form of parental injustice when implementing a zoning policy is the occurrence of a blank spot area that causes limitations in choosing schools for students who come from the blank spot area. The limitations in choosing schools also occur in areas where the distribution of schools is limited. Another disappointment at the zoning policy is not using grades in-school registration.

\section{Acknowledgment}

The author thanks the Kemenristek Dikti for providing research grants to researchers so that they can assist the authors in the research process and the preparation of this article.

\section{References}

[1] S. U. S, "Arah pendidkan di Indonesia dalam tataran kebijakan dan implementasi," Form. J. Ilm. Pendidik. MIPA, vol. 2, no. 2, pp. 111-121, 2012.

[2] BPS, Potret Pendidikan Indonesia Statistik Pendidikan 2017, vol. (5)2, no. 2. 1394.

[3] BPS, "Potret Pendidikan Indonesia Statistik Pendidikan 2018," 2018.

[4] H. M. Gunter and G. Forrester, "School leadership and education policy-making in England," Policy Stud., vol. 30, no. 5, pp. 495-511, 2009.

[5] Lolytasari, "UU NO 14 Tahun 2008," J. Chem. Inf., vol. 53, no. 9, pp. 1689-1699, 2013.

[6] C. Musil, "Women's studies: Overview," in Routledge International Encyclopedia of Women: Global women's issues and knowledge, 2000.

[7] M. of Education, "DIKBUD_MAJALAH_edisi4_OK.pdf." 2016. 
[8] B. Satriatna, S. Zahra, and M. Fahmi, "Working Paper Impact of School Zoning : A Review of The Economic Literature," no. 6, 2018.

[9] S. L. Andrew and J. A. Orodho, "Socio- Economic Factors Influencing Pupils' Access To Education in Informal Settlements : a Case of Kibera, Nairobi County, Kenya," Int. J. Educ. Res., vol. 2, no. 3, pp. 1-16, 2014.

[10] M. A. Wahyudi and A. Lutfi, "Analisis Reformasi Pendidikan dalam Mewujudkan Pemerataan Kualitas Pendidikan di Indonesia Analysis of Education Reforms in Realizing even Distribution of Quality Education in Indonesia Sejalan dengan tujuan Grand Design dalam proses Penerimaan Peserta Di," J. Adm. Public (Public Adm. Journal), vol. 9, no. 2, pp. 191-201, 2019.

[11] \& R. H. . Suryana, Y., Pendidikan multikultural suatu upaya penguatan jati diri bangsa:konsep-prinsipimplementasi. 2005.

[12] Polama M, Sosiologi Kontemporer. 2010.

[13] Fisher, Mengelola konflik: keterampilan dan strategi untuk bertindak. 2001.

[14] T. P. Kurnianingrum, "Permendikbud no. 14 tahun 2018 dari perspektif keadilan," Info Singk. 14, vol. 10, no. 14 , pp. 1-6, 2018.

[15] P. D. Kusuma, "Distance-score combined model in automatic high school student enrollment system," $J$. Theor. Appl. Inf. Technol., vol. 96, no. 20, pp. 6699-6713, 2018.

[16] Irianto, Kebijakan pembaruan pendidikan konsep, teori dan model. 2011.

[17] W. Khairunnisa, "Jurnal Pendidikan Kewarganegaraan Undiksha Vol. 8 No. 2 (Mei, 2020),” vol. 8, no. 2, pp. $46-$

56,2020 